\title{
RET Gene Product
}

National Cancer Institute

\section{Source}

National Cancer Institute. RET Gene Product. NCI Thesaurus. Code C105525.

A protein encoded by the RET gene. 